
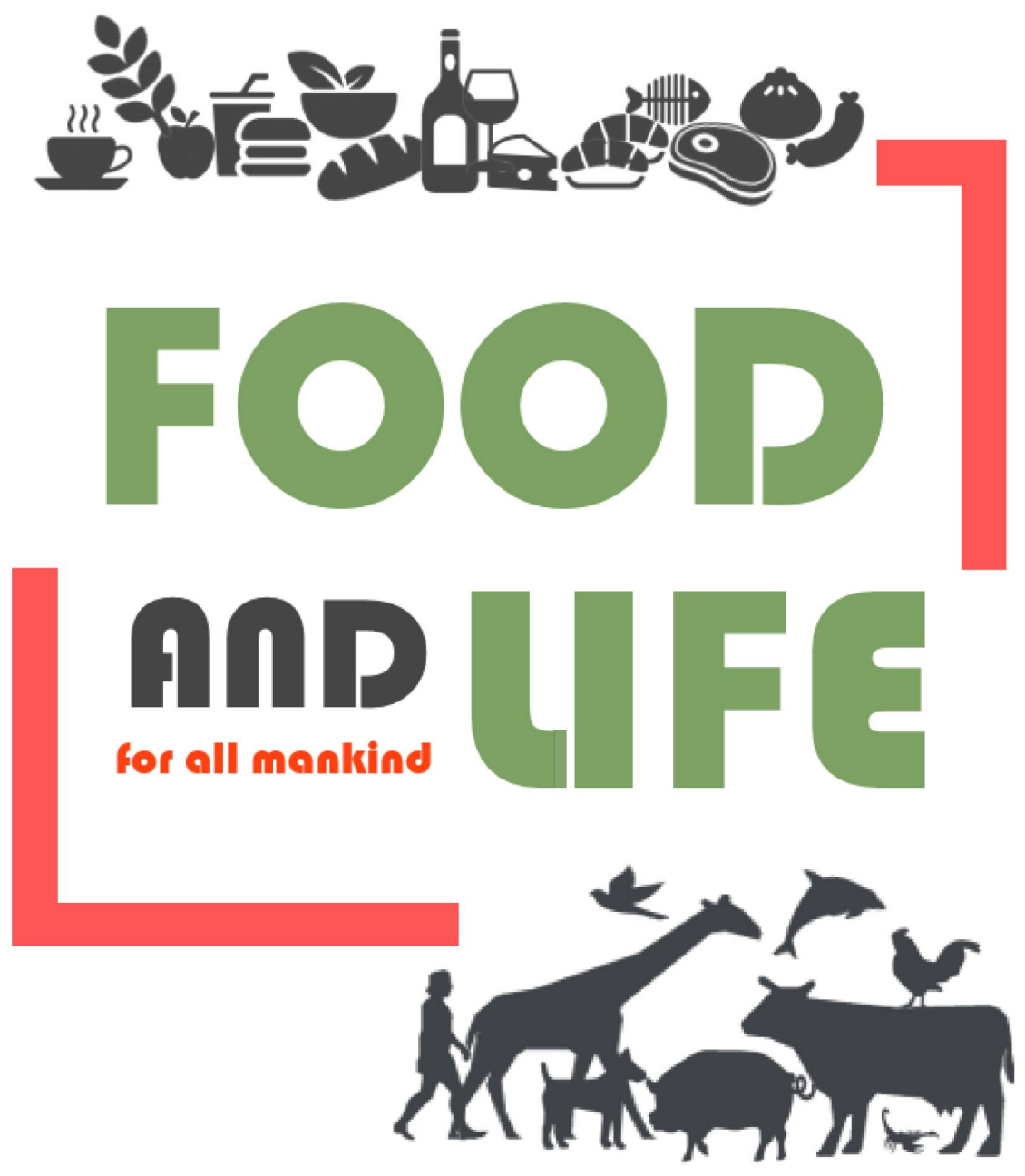

The Food and Life has published all type articles such as research articles, review articles, survey articles, research note, short communication or editorial since 2020. It covers the all scientific and technological aspects of food and life science.

\title{
https://www.foodnlife.org
}




\title{
동물복지 육계(Cobb) 다리육의 이화학적 특성과 생리활성기능 성분
}

\author{
김희진 ${ }^{1,2}$, 김동욱 ${ }^{1}$, 김혜진 ${ }^{1}$, 권지선 $^{1}$, 장애라 $^{1, *}$ \\ 1강원대학교 동물생명과학대학 동물응용과학과 \\ 2국립축산과학원 가금연구소
}

\section{Physicochemical characteristics and bioactive compounds of thigh meat from Cobb broiler in animal welfare farm}

\author{
Hee-Jin Kim¹,2, Dongwook Kim¹, Hye-Jin Kim¹, Ji-Seon Kwon', Aera Jang ${ }^{1, *}$ \\ ${ }^{1}$ Department of Applied Animal Science, College of Animal Life Science, Kangwon National University, Chuncheon 24341, Korea \\ ${ }^{2}$ Poultry Research Institute, National Institute of Animal Science, Pyengchang 25342, Korea
}

\begin{abstract}
This study was performed to evaluate physicochemical characteristics and bioactive compounds of chicken thigh meat of broilers (Cobb) from animal welfare farm. Carcass of broilers from conventional $(n=30)$ and animal welfare certified farms $(n=30)$ were packaged and stored in cold incubator at $4 \pm 1^{\circ} \mathrm{C}$ for 9 days. Physicochemical properties and bioactive compounds of thigh meat were determined on day 1, 3, 5, 7, and 9. There was no significant difference in proximate composition and redness. Shear force of thigh meat from animal welfare farm was higher than thigh meat from conventional farm during entire storage $(\rho\langle 0.05)$. Total aerobic bacteria (TAB) counts of chicken thigh meat from animal welfare farm were significantly lower than it from conventional farm on day 7 and 9. Also, as a lipid oxidation value, 2-thiobarbituric acid reactive substance of thigh from animal welfare farm was significantly lower than that of it from conventional farm $(p<0.05)$. Creatine, creatinine, anserine, and carnosine were not affected by welfare farming during storage. Therefore, this study suggests that Cobb chicken thigh meat from animal welfare farm showed lower TAB, lower lipid oxidation, and higher shear force value than thigh meat from conventional farm after storage day 7. This data can be used as a preliminary data for sustainable production of broilers based on animal welfare farming system in Korea.
\end{abstract}

Keywords: welfare, broilers, quality, Cobb, bioactive compounds

\section{서 론}

최근 소비자들은 식육의 구입 시 안전성, 품질, 가격 등과 같 은 요소와 더불어 가축의 사육 시 복지 수준에 대한 정보도 관 심을 가지고 있다. 지난 2017년 살충제 계란과 조류인플루엔자 의 발생으로 가금산물에 많은 문제가 발생되면서 동물복지육 계는 지속적인 주목을 받아왔다. 일반 농가에서 생산된 육계보 다 동물복지인증 농장에서 생산된 육계의 가격이 $30 \%$ 가량 높 음에도 불구하고 동물복지 상품을 구매하고 있으며, 특히 코로 나 19로 인하여 전세계적인 팬데믹 상황으로 지친 많은 소비자 들은 안전하고 몸에 좋은 건강한 식재료를 찾고 더 깊은 관심 을 보이고 있다.

이에 맞추어 최근 동물복지인증 육계농가는 크게 증가하고
있는데, 2021년 7월 기준 동물복지인증 육계농가는 124호로 2018년(56호) 대비 2배 이상 증가하였다. 육계 사육단계에서 동물복지인증을 받으려면 사육밀도는 계사 내 19 수 $/ \mathrm{m}^{2}$ 및 30 $\mathrm{kg} / \mathrm{m}^{2}$ 이하, 1,000 수당 횃대 $2 \mathrm{~m}$ 제공(굵기 직경 3-6 cm, 벽에 서 $20 \mathrm{~cm}$, 바닥에서 10-100 cm 간격 유지), 조도는 일일 최소 8시간 이상 연속 점등(20 lux 이상) 및 최소 6시간 이상 소등하 고, 암모니아 농도와 $\mathrm{CO}_{2}$ 농도는 각각 $25 \mathrm{ppm}$ 미만, 5,000 $\mathrm{ppm}$ 미만이어야 한다(Kim et al., 2018). 또한 계사 내 모든 바 닥은 깔짚으로 덮어 충분한 깊이를 유지하게 하고, 닭의 본성 인 쪼는 행동을 할 수 있도록 양배추 및 채소 등을 넣어주어야 한다. 실제 유통 현장에서도 일반적인 사육 및 출하방법 대신 동물복지 시스템으로 사육하고 출하한 경우 품질향상에 긍정

\footnotetext{
"Corresponding author : Aera Jang. Department of Applied Animal Science, Kangwon National University, Chuncheon 24341, Korea. Tel: +82-33-250-8643, Fax: +82-33-251-7719, E-mail: ajang@kangwon.ac.kr

This is an Open-Access article distributed under the terms of the Creative Commons Attribution Non-Commercial License which permits unrestricted non-commercial use, distribution, and reproduction in any medium, provided the original work is properly cited (http://creativecommons.org/licenses/by-nc/4.0/).
} 
적인 영향을 나타내는 것으로 보고되고 있다. 특히 사육단계에 서 깔짚의 관리가 엄격하게 관리될 경우, 발바닥 피부염과 무 릎지루, 가슴수포 등의 발생이 $50 \%$ 이상 낮아져 닭의 건강이 크 게 증가하였다(Jeon, 2020). 또한 육계 운송 시 플라스틱 어리 장의 사용이 철제 어리장을 이용한 경우보다 $1+$ 등급 출현율이 각각 $62 \%$ 와 $43 \%$ 를 보여 품질이 개선됨을 나타내었다.

그러나 소비자가 궁금해 하는 동물복지 육계의 품질에 대한 연구는 아직도 크게 부족하다. 유사한 연구로 $\operatorname{Kim}$ 등(2018)은 국내 일반 및 동물복지 육계(Arbor Acres) 다리육의 냉장저장기 간 중 품질과 생리활성 기능성분을 비교하였는데, 동물복지형 육 계 다리육의 전단력이 다소 높았으며, 단백질 변패도를 나타내는 휘발성염기태질소 함량이 모든 저장일차에서 일반농장에서 생산 된 육계보다 낮아 신선도를 더 오래 유지했다고 보고하였다. 그 러나 Cobb종 동물복지육계 다리육에 대한 연구는 거의 없다.

따라서 본 연구는 Cobb종 동물복지육계 다리육을 냉장저장 하면서 일반농장에서 생산된 Cobb육계와 이화학적 품질특성 및 생리활성기능 성분의 차이를 규명하고, 동물복지육계 다리 육의 특성에 대한 기초자료로 활용하기 위해 실시하였다.

\section{재료 및 방법}

\section{공시시료}

일반농장 $(\mathrm{n}=30)$ 과 동물복지인증농장 $(\mathrm{n}=30)$ 에서 35 일 동안 사육한 도계 체중 $1.1 \mathrm{~kg}$ 의 Cobb종 육계를 도계 후 바로 구입 하여 냉장온도 $\left(2 \pm 2^{\circ} \mathrm{C}\right)$ 에서 실험실로 옮긴 뒤 다리육을 발골하 였다. 발골한 일반농장 다리육(CT)과 동물복지 다리육(WT)은 각각 스티로폼 트레이에 $\mathrm{LDPE(low} \mathrm{density} \mathrm{polyethylene)으로}$ 랩 포장하여 저온 인큐베이터 $\left(4 \pm 1^{\circ} \mathrm{C}\right)$ 에서 $1,3,5,7,9$ 일 동안 저장하면서 실험에 사용하였다.

\section{이화학적 특성}

\section{일반성분}

일반성분 분석은 AOAC의 방법(AOAC International, 1995) 에 따라 수분, 조지방, 조회분, 조단백질 함량을 측정하였다.

\section{$\mathrm{pH}$}

식육의 $\mathrm{pH}$ 는 시료 $10 \mathrm{~g}$ 에 증류수 $90 \mathrm{~mL}$ 를 가하여 homogenizer(PolyTron PT-2500 E, Kinematica, Lucerne, Switzerland) 를 사용하여 균질화한 후, $\mathrm{pH}$ meter(Orion 230A, Thermo Fisher Scientific, Waltham, MA, USA)를 이용하여 측정하였다.

\section{육색}

육색은 색차계(Colormeter CR-300, Minolta, Osaka, Japan)
를 이용하여 측정하였다. 명도 $\left(\mathrm{L}^{*}\right)$, 적색도 $\left(\mathrm{a}^{*}\right)$, 황색도 $\left(\mathrm{b}^{*}\right)$ 의 값은 동일한 방법으로 반복 측정하여 평균값을 나타내었다. 표 준화 작업은 $\mathrm{Y}$ 값이 84.6, $\mathrm{x}$ 값이 $0.3174, \mathrm{y}$ 값이 0.3241 인 표준백 판을 사용하였다.

\section{가열감량}

시료를 polyethylene bag에 넣고 식육의 심부온도가 $75 \pm 2^{\circ} \mathrm{C}$ 에 도달할 때까지 항온수조에서 45 분간 가열 후, 가열 전후의 중량차이를 백분율로 환산하여 가열감량을 계산하였다.

가열감량 $(\%)=[($ 가열 전 무게 - 가열 후 무게 $) /$ 가열 전 무게 $] \times 100$

\section{보수력}

근막(힘줄)을 제거한 시료를 약 $0.5 \mathrm{~g}$ 측량하여 시험관에 넣 고 $80^{\circ} \mathrm{C}$ 의 항온 수조에서 20 분간 가열 후 10 분 동안 실온에서 방냉하였다. 이후 $2,000 \times \mathrm{g}$ 에서 20 분간 원심분리한 다음 시료의 무게를 측정하고, 다음의 식을 이용하여 보수력을 계산하였다.

$$
\begin{aligned}
& \text { 보수력 }(\%)=[(\text { 총 수분 }- \text { 유리수분 }) / \text { 총 수분 }] \times 100 \\
& \text { 유리수분 }=[(\text { 원심분리 전 무게 }- \text { 원심분리 후 무게 }) / \\
& \text { (시료×지방계수 })] \times 10 \\
& \text { 지방계수 }=1-(\text { 지방함량 } / 100)
\end{aligned}
$$

\section{전단력}

시료를 polyethylene bag에 넣고 닭 다리육의 심부 온도가 $75 \pm 2^{\circ} \mathrm{C}$ 에 도달할 때까지 항온수조에서 45 분간 가열한 후, 근섬 유 방향과 평행이 되도록 $3 \times 1 \times 2 \mathrm{~cm}$ 로 잘라 준비하였으며, 측정 시 근섬유 방향과 직각으로 하여 분석하였다. 전단력은 Texture Analyzer TA 1(LLOYD instruments, Fareham, UK)를 이용하 였으며, V blade로 측정하였다. Texture analyzer의 측정 조건은 $500 \mathrm{~N}$ load cell을 사용하였으며, cross-head speed은 $50 \mathrm{~mm} /$ $\min$ 이었다.

\section{미생물(총균수 및 대장균/대장균군)}

총균수와 대장균/대장균군은 Petrifilm(Aerobic Count Plates, Coliform/E.coli Count Plates, 3M, Paul, MN, USA)을 이용하여 측정하였다. 시료 $10 \mathrm{~g}$ 을 채취한 다음 멸균 생리 식염수 $90 \mathrm{~mL}$ 와 함께 멸균 bag에 넣고, stomacher(BagMixer 400; Interscience, France)를 이용하여 1 분 동안 균질화 하였다. 균질액을 멸균 생 리 식염수로 희석하여 petrifilm에 $1 \mathrm{~mL}$ 를 접종하였다. Petrifilm 은 $37^{\circ} \mathrm{C}$ 에서 48 시간 배양한 후, 군락 수를 계수하여 나타내었다.

\section{Thiobarbituric acid reactive substances(TBARS)}

TBARS 측정은 Buege와 Aust(1978)의 방법을 이용하였다. 
시료 $5 \mathrm{~g}$ 에 $15 \mathrm{~mL}$ 증류수를 넣은 후 7.2\% butylated hydroxyl toluene $0.05 \mu \mathrm{L}$ 를 첨가하여 균질하였다. 균질액 $1 \mathrm{~mL}$ 에 $2 \mathrm{~mL}$ 의 $20 \mathrm{mM}$ 2-thiobarbituric acid(in $15 \%$ trichroacetic acid) 시약 을 가하고, $90^{\circ} \mathrm{C}$ 에서 15 분간 가열하였다. 가열 후 찬물에서 10 분간 식힌 다음 $2,000 \times \mathrm{g}$ 에서 10 분간 원심분리하였다. 원심분리 후 상층액을 UV/VIS spectrophotometer(Molecular Device, $\mathrm{M} 2 \mathrm{e}$, Sunnyvale, CA, USA)를 이용하여 $531 \mathrm{~nm}$ 에서 흡광도를 측정하였고, 공시료는 시료대신 증류수를 가하여 같은 방법으 로 측정하였다. TBARS 값은 흡광도 수치에 5.88 을 곱하여 나 타내었다.

$\operatorname{TBARS}$ 값 $(\mathrm{mg}$ malondialdehyde $/ \mathrm{kg}$ sample) $=$ (시료 흡광도 - 공시료 흡광도) $\times 5.88$

\section{휘발성염기태질소(volatile basic nitrogen, VBN)}

시료 내 VBN 함량은 Conway unit을 사용하는 미량확산법 을 이용하여 측정하였다(Kim et al., 2018). 시료 $10 \mathrm{~g}$ 에 $50 \mathrm{~mL}$ 증류수를 넣고 30 분간 교반을 실시한 후 여과지(Whatman No. 1)를 이용하여 여과하였다. Conway unit 외실에는 시료 여과액 과 포화 $\mathrm{K}_{2} \mathrm{CO}_{3}$ 각각 $1 \mathrm{~mL}$ 를 넣고 내실에는 $0.01 \mathrm{~N} \mathrm{H}_{2} \mathrm{SO}_{4} 1$ $\mathrm{mL}$ 를 첨가하여 즉시 밀폐하였다. 밀폐한 Conway unit을 $25^{\circ} \mathrm{C}$ 암실에서 1시간 방치한 후 Conway unit 내실에 Brunswik 지시 약( $0.2 \mathrm{~g}$ methyl red와 $0.1 \mathrm{~g}$ methylene blue $/ 100 \mathrm{~mL}$ ethanol)을 첨가하고 $0.01 \mathrm{~N} \mathrm{NaOH}$ 로 적정하였다. 휘발성 염기태 질소의 함량은 다음과 같은 식을 이용하여 계산하였다.

$\mathrm{VBN}(\mathrm{mg} / 100 \mathrm{~g})=0.14 \times(\mathrm{b}-\mathrm{a}) \times \mathrm{F} \div \mathrm{W} \times 100 \times \mathrm{D}$

$\mathrm{a}$, 시료의 적정한 $\mathrm{NaOH}$ 의 양 $(\mathrm{mL}) ; \mathrm{b}$, 공시료의 적정한 $\mathrm{NaOH}$ 의 양 $(\mathrm{mL}) ; \mathrm{F}, 0.01 \mathrm{~N} \mathrm{NaOH}$ 의 표준화 지수; $\mathrm{W}$, 시료의 무게 $(\mathrm{g})$; D, 희석배수

\section{지방산 조성}

지방산 조성은 Folch 등(1957)의 방법에 따라 Folch 용액 (chloroform:methanol=2:1)을 사용하여 지방을 추출하였으며, 시료를 시험관에 취한 후, $0.5 \mathrm{~N}$ 의 $\mathrm{NaOH}$-메탄올 용액 $1.5 \mathrm{~mL}$ 를 첨가하여 vortex로 혼합한 뒤에 $100^{\circ} \mathrm{C}$ 에서 5 분 동안 가열하 였다. 찬물에서 냉각 후, $\mathrm{BF}_{3}$-메탄올 용액(약 $10 \%$, Supelco, Bellefonte, PA, USA) $2 \mathrm{~mL}$ 를 첨가하고, vortex한 후에 $100^{\circ} \mathrm{C}$ 에서 2 분 동안 다시 가열한 후 냉각하였다. 지방산 메틸에스테 르(fatty acid methyl ester, FAME)들을 추출하기 위하여 isooctane $2 \mathrm{~mL}$ 를 첨가한 후 1 분 동안 vortex하였다. 다음 포화 $\mathrm{NaCl}$ 용액 $1 \mathrm{~mL}$ 를 가한 후 1 분 동안 충분히 vortex한 후에, 원 심분리기 $(738 \times \mathrm{g}, 3$ 분 $)$ 를 이용하여 층분리하였다. FAME를 포 함한 상층액(iso-octane층)을 $\mathrm{GC}$ vial에 옮겨 분석하였다. 가스
크로마토그래피 분석조건은 Table 1에 나타내었다. 결과는 표 준물질(PUFA No. 2 - Animal Source, Supelco)을 기준으로 전 체 지방산 peak 면적에 대한 각각 지방산의 면적을 \%로 환산 하여 나타내었다.

\section{생리활성물질(creatine, creatinine, di-peptide)}

식육 내 creatine, creatinine 및 di-peptide(carnosine, anserine) 함량은 Mora 등(2007)의 방법을 이용하였다. 시료 $2.5 \mathrm{~g}$ 에 0.01 $\mathrm{N} \mathrm{HCl} 7.5 \mathrm{~mL}$ 를 첨가하여 균질하였다. 균질 후 $4^{\circ} \mathrm{C}$ 에서 $3,000 \times \mathrm{g}$ 으로 30 분간 원심분리한 후 상층액을 Whatman Glass microfiber Filter GF/C를 이용하여 여과하였다. 여과액 $250 \mu \mathrm{L}$ 를 acetonitrile $750 \mu \mathrm{L}$ 와 혼합하여 $4^{\circ} \mathrm{C}$ 에서 20 분간 반응시켰다. 반응 후, $10,000 \times \mathrm{g}$ 에서 10 분 동안 원심 분리한 후 상등액을 $0.22 \mu \mathrm{m}$ membrane filter로 여과하여 HPLC(Agilent Infinity 1260 series, Agilent Technologies, Palo Alto, CA, USA) 분석 에 이용하였다. 분석 컬럼은 Atlantis HILIC silica column (150×4.6 mm, $3.0 \mu \mathrm{m}$, Waters, Milford, MA, USA)을 사용하였 으며, 컬럼 온도는 $35^{\circ} \mathrm{C}$ 로 하였다. Creatine, anserine, carnosine은 $214 \mathrm{~nm}$ 에서 검출하였으며, creatinine은 $236 \mathrm{~nm}$ 에서 검출하였다. 이동상은 A 용매가 $0.65 \mathrm{mM}$ ammonium acetate/acetonitrile[pH 5.50, 35:75(v/v)], B 용매가 $0.55 \mathrm{mM}$ ammonium acetate/ acetonitrile[pH 5.50, 70:30(v/v)]로 B 용매를 $1.4 \mathrm{~mL} / \mathrm{min}$ 의 유 속으로 13 분 동안 linear gradient $(0 \%-100 \%)$ 방법으로 분석하 였다. 각각 표준물질은 Sigma-Aldrich(St. Louis, MO, USA)에 서 구입하여 사용하였으며, 표준물질의 처리 농도에 따른 면적 비율을 계산하여 $\mathrm{mg} / 100 \mathrm{~g}$ 로 나타내었다.

\section{항산화 활성}

DPPH(2,2-diphenyl-1-picrylhydrazyl) 라디칼 소거능은 Blois

Table 1. Operating conditions of gas chromatography for determination of fatty acid composition

\begin{tabular}{|c|c|}
\hline Item & Condition \\
\hline Instrument & Agilent 6890N, Agilent Technologies, USA \\
\hline Column & $\begin{array}{l}\text { Omegawax } 250 \\
(30 \mathrm{~m} \times 0.25 \mathrm{~mm} \text { id, } 0.25 \mu \mathrm{m} \text { film } \\
\text { thickness; Supelco, Bellefonte, PA, USA) }\end{array}$ \\
\hline Detector & Flame Ionization Detector \\
\hline Carrier gas & Helium (99.99\%, Research purity) \\
\hline \multicolumn{2}{|c|}{ Column flow rate $1.2 \mathrm{~mL} / \mathrm{min}$} \\
\hline Split ratio & 100:1, $1 \mu \mathrm{L}$ (Injection volume) \\
\hline $\begin{array}{l}\text { Injection port } \\
\text { temperature }\end{array}$ & $250^{\circ} \mathrm{C}$ \\
\hline $\begin{array}{l}\text { Detection port } \\
\text { temperature }\end{array}$ & $260^{\circ} \mathrm{C}$ \\
\hline $\begin{array}{l}\text { Oven } \\
\text { temperature }\end{array}$ & $\begin{array}{l}150^{\circ} \mathrm{C} \text {, hold for } 2 \mathrm{~min} \\
4^{\circ} \mathrm{C} / \mathrm{min} \text { up to } 220^{\circ} \mathrm{C} \text {, hold for } 30 \mathrm{~min}\end{array}$ \\
\hline
\end{tabular}


(1958)의 방법을 이용하여 분석하였다. 메탄올에 용해시킨 0.2 $\mathrm{mM} \mathrm{DPPH}$ 용액 $100 \mu \mathrm{L}$ 에 각 시료를 $100 \mu \mathrm{L}$ 씩 혼합하여 실온 암실에서 30 분간 반응시킨 후 micro plate reader(SpectraMax $\mathrm{M} 2 \mathrm{e}$, Molecular Devices)를 사용하여 $517 \mathrm{~nm}$ 에서 흡광도를 측 정하였다.

ABTS(2,2' -azino-bis-(3-ethylbenzothiazoline-6-sulfonic acid) 라디칼 소거 활성은 $\operatorname{Re}$ 등(1999)의 방법을 이용하여 측정하였 다. $14 \mathrm{mM} \mathrm{ABTS}$ 용액과 $4.9 \mathrm{mM}$ potassium persulphate 용액 을 1:1로 혼합하고, ABTS 라디칼을 만들기 위해 실온에서 1216 시간 동안 암소에서 반응시켰다. 라디칼이 생성된 용액을 $735 \mathrm{~nm}$ 에서 흡광도 값이 $0.700 \pm 0.02$ 가 되도록 희석하였다. 그 후 시료 $50 \mu \mathrm{L}$ 와 $\mathrm{ABTS}^{+}$용액 $950 \mu \mathrm{L}$ 를 혼합하여 $30^{\circ} \mathrm{C}$ 암실 에서 30 분간 반응시킨 다음 $735 \mathrm{~nm}$ 에서 흡광도를 측정하였다. 결과는 Trolox를 표준물질로 하여 $\mu \mathrm{M} \mathrm{TE} / \mathrm{mg}$ dry matter로 나 타내었다.

FRAP(ferric reducing antioxidant power) 활성은 Benzie와 Strain(1996)의 방법을 이용하여 항산화 활성을 측정하였다. FRAP solution은 $300 \mathrm{mM}$ acetate buffer(pH 3.6)와 $40 \mathrm{mM}$ $\mathrm{HCl}$ 로 용해시킨 $10 \mathrm{mM}$ 2,4,6-tripyridyl-S-triazine(TPTZ) 용액 및 $20 \mathrm{mM} \mathrm{FeCl}{ }_{3} \cdot 6 \mathrm{H}_{2} \mathrm{O}$ 를 각각 10:1:1의 비율로 혼합하여 사 용하였다. 시료 $25 \mu \mathrm{L}$ 와 FRAP solution $175 \mu \mathrm{L}$ 를 넣어 $37^{\circ} \mathrm{C}$ 에 서 30 분간 방치 후 $590 \mathrm{~nm}$ 에서 흡광도를 측정하였다. 결과는 trolox를 표준물질로 하여 $\mu \mathrm{M} \mathrm{TE} / \mathrm{mg}$ dry matter로 계산하여 나 타내었다.

ORAC(oxygen radical absorbance capacity)은 Gillespie 등 (2007)의 방법에 따라 96 well plate에 $25 \mu \mathrm{L}$ 시료를 넣고, 150 $\mu \mathrm{L}$ fluorescein $(80 \mathrm{nM})$ 을 넣어 혼합한 뒤 $37^{\circ} \mathrm{C}$ incubator에서 15
분 동안 방치하였다. 이 후 $25 \mu \mathrm{L} \mathrm{AAPH}(150 \mathrm{mM})$ 을 넣고 완전 하게 혼합한 뒤 fluorescent microplate reader(SpectraMax M2e, Molecular Devices)를 사용하여 $37^{\circ} \mathrm{C}$ 에서 excitation 파장 485 $\mathrm{nm}$ 와 emission 파장 $520 \mathrm{~nm}$ 에서 60 분 동안 1 분 간격으로 fluorescence의 감소율을 측정하였다. 표준시약(trolox)과 시료 의 area under the curve(AUC)를 측정하였으며, 표준시약 농도 와 $\mathrm{AUC}$ 간의 회귀곡선을 이용하여 $\mu \mathrm{M} \mathrm{TE} / \mathrm{mg}$ dry matter로 나타내었다.

\section{통계분석}

본 실험의 결과는 SAS(statistics analytical system) 프로그램 (ver. 9.4)을 이용하여 처리구 및 저장 일차에 따른 차이분석을 위해 분산분석을 실시하였으며, Tukey's 방법을 이용하여 $p<0.05$ 수준에서 평균값 간의 유의성을 검정하였다. 모든 데이 터 값은 평균값과 평균표준오차(SEM)로 나타내었다.

\section{결과 및 고찰}

\section{이화학적 특성}

\section{일반성분조성}

국내 일반 및 동물복지 육계 다리육의 저장 기간 중 일반성 분 함량은 Table 2에 나타내었다. 수분, 조단백질, 조지방, 조회 분 함량은 각각 $74.73 \%-75.88 \%, 17.87 \%-19.42 \%, 6.19 \%-6.56 \%$, $1.67 \%-1.72 \%$ 를 나타내었으며, 저장기간 및 처리구 간의 유의 적인 차이는 없었다( $p>0.05) . \mathrm{Kim}$ 등(2018)은 동물복지 인증 및 일반육계(Arbor Acres) 닭다리의 수분, 조단백질, 조지방, 조회

Table 2. Proximate composition (\%) of chicken thigh meat from conventional and animal welfare farm during cold storage

\begin{tabular}{|c|c|c|c|c|c|c|c|}
\hline \multirow{2}{*}{ Items } & \multirow{2}{*}{ Treatment } & \multicolumn{5}{|c|}{ Storage (d) } & \multirow{2}{*}{ SEM } \\
\hline & & 1 & 3 & 5 & 7 & 9 & \\
\hline \multirow[t]{3}{*}{ Moisture } & CT & 75.09 & 75.83 & 74.92 & 75.80 & 75.29 & 0.538 \\
\hline & WT & 75.99 & 75.88 & 74.84 & 74.73 & 75.49 & 0.393 \\
\hline & SEM & 0.526 & 0.616 & 0.271 & 0.293 & 0.544 & \\
\hline \multirow[t]{3}{*}{ Crude protein } & CT & 18.92 & 18.40 & 18.40 & 17.87 & 18.97 & 0.338 \\
\hline & WT & 18.94 & 19.31 & 19.42 & 18.23 & 18.59 & 0.385 \\
\hline & SEM & 0.372 & 0.405 & 0.391 & 0.270 & 0.358 & \\
\hline \multirow[t]{3}{*}{ Crude fat } & CT & 6.56 & 6.53 & 6.26 & 6.21 & 6.30 & 0.371 \\
\hline & WT & 6.31 & 6.19 & 6.40 & 6.32 & 6.55 & 0.330 \\
\hline & SEM & 0.319 & 0.345 & 0.387 & 0.398 & 0.294 & \\
\hline \multirow[t]{3}{*}{ Crude ash } & $\mathrm{CT}$ & 1.72 & 1.72 & 1.70 & 1.67 & 1.71 & 0.045 \\
\hline & WT & 1.69 & 1.71 & 1.72 & 1.71 & 1.71 & 0.043 \\
\hline & SEM & 0.046 & 0.036 & 0.054 & 0.038 & 0.043 & \\
\hline
\end{tabular}

$\mathrm{CT}$, chicken thigh meat from conventional farm; WT, chicken thigh meat from animal welfare farm. 
분 함량은 각각 $74.95 \%-75.75 \%, 17.34 \%-17.76 \%, 5.80 \%-6.63 \%$, $1.12 \%-1.35 \%$ 를 보였으며, 처리구 간의 유의적인 차이를 보이 지 않아 본 연구와 유사한 값을 나타내었다.

\section{$\mathrm{pH}$, 육색, 가열감량, 보수력}

국내 일반 및 동물복지 육계 다리육의 저장 기간 중 $\mathrm{pH}$, 육 색, 가열감량, 보수력의 변화는 Table 3 에 나타내었다. $\mathrm{pH}$ 는 6.52-7.07을 나타내었다. 일반농장육계의 $\mathrm{pH}$ 값은 저장 1 일차 보다 저장 9일차에 유의적으로 높은 수치를 나타내었으나 $(p<0.05)$, 동물복지농장 육계는 저장기간 동안 유의적인 차이 를 보이지 않았다 $(p>0.05)$. 식육의 저장기간 동안 $\mathrm{pH}$ 가 증가하 는 것은 미생물의 증식과 단백질의 분해에 의해 생산된 암모니 아와 대사산물에 의한 것으로 판단된다(Jay and Shelef, 1987). Castellini 등(2002)은 유기농장에서 사육한 육계 다리육의 $\mathrm{pH}$ 가 일반농장 육계 다리육보다 유의적으로 낮은 $\mathrm{pH}$ 를 보였다고 하였으나, Husak 등(2008)의 연구에서는 유기농장과 일반농장 에서 사육된 육계 다리육의 $\mathrm{pH}$ 는 유의적인 차이를 보이지 않 았다고 보고하였다.

육색은 소비자가 식육을 구매하는 데 있어 영양을 미치는 중
요한 요소이며, 육계의 종류, 사육환경, 나이 등에 영향을 받는 것으로 알려져 있다(Kim et al., 2020). L*(52.84-53.75) 결과 값 은 모든 저장 기간 동안 두 처리구 간의 유의적인 차이가 없었 다 $(p>0.05)$. Husak 등(2008)은 일반 농장과 방목 농장의 육계 다리육의 $\mathrm{L}^{*}$ 값은 유의적인 차이가 없었다고 보고하였다. 적색 도를 나타내는 $\mathrm{a}^{*}$ 값은 모든 저장 일차 동안 WT 처리구(8.248.56)가 CT 처리구(6.50-6.89)보다 유의적으로 높은 값을 나타 내었으며 $(p<0.05)$, 두 처리구 모두 저장기간에 따른 유의적인 차이를 보이지 않았다( $p>0.05)$. Husak 등(2008)의 연구에서 방 목된 육계 다리육의 $\mathrm{a}^{*}$ 값이 일반농장에서 사육된 육계 다리육 보다 유의적으로 높아, 본 연구와 유사한 경향을 나타내었다. 황색도를 나타내는 $b^{*}$ 값은 두 처리구 모두 저장 시간이 경과함 에 따라 증가하였으며 $(p<0.05)$, 저장 7,9 일차에는 $\mathrm{WT}$ 처리구 가 CT 처리구보다 낮은 황색도를 나타내었다 $(p<0.05)$.

가열 감량과 보수력은 식육 내 수분을 유지할 수 있는 능력 을 평가하는 데 사용되고 있으며(Choi et al., 2009), 보수력은 식육의 색도, 다즙성, 연도 등에 영향을 미친다. 다리육 내 가열 감량은 $25.56 \%-29.88 \%$ 를 나타내었으며, 처리구 간 및 저장기 간에 따른 유의적인 차이를 보이지 않았다( $p>0.05)$. 또한 모든

Table 3. $\mathrm{pH}$, instrumental color, cooking loss (\%) and water holding capacity (WHC, \%) of chicken thigh meat from conventional and animal welfare farm during cold storage

\begin{tabular}{|c|c|c|c|c|c|c|c|c|}
\hline \multirow{2}{*}{\multicolumn{2}{|c|}{ Items }} & \multirow{2}{*}{ Treatment } & \multicolumn{5}{|c|}{ Storage (days) } & \multirow{2}{*}{ SEM } \\
\hline & & & 1 & 3 & 5 & 7 & 9 & \\
\hline \multirow{3}{*}{\multicolumn{2}{|c|}{$\mathrm{pH}$}} & $\mathrm{CT}$ & $6.59^{b}$ & $6.59^{b}$ & $6.78^{\mathrm{Ab}}$ & $6.76^{\mathrm{Ab}}$ & $7.07^{a}$ & 0.046 \\
\hline & & WT & 6.52 & 6.54 & $6.59^{\mathrm{B}}$ & $6.56^{\mathrm{B}}$ & 6.59 & 0.029 \\
\hline & & SEM & 0.037 & 0.039 & 0.053 & 0.034 & 0.027 & \\
\hline \multirow[t]{9}{*}{ Color } & $L^{*}$ & CT & 53.26 & 53.21 & 53.00 & 52.65 & 52.84 & 0.464 \\
\hline & & WT & 53.75 & 52.91 & 53.03 & 53.02 & 53.09 & 0.475 \\
\hline & & SEM & 0.335 & 0.748 & 0.285 & 0.494 & 0.325 & \\
\hline & $a^{*}$ & $\mathrm{CT}$ & $6.50^{\mathrm{B}}$ & $6.53^{B}$ & $6.64^{\mathrm{B}}$ & $6.89^{\mathrm{B}}$ & $6.72^{\mathrm{B}}$ & 0.218 \\
\hline & & WT & $8.56^{\mathrm{A}}$ & $8.29^{A}$ & $8.38^{\mathrm{A}}$ & $8.24^{\mathrm{A}}$ & $8.39^{A}$ & 0.200 \\
\hline & & SEM & 0.195 & 0.310 & 0.154 & 0.206 & 0.134 & \\
\hline & $b^{*}$ & $\mathrm{CT}$ & $8.20^{\circ}$ & $9.26^{b c}$ & $10.57^{b}$ & $12.38^{\mathrm{Aa}}$ & $12.38^{\mathrm{Aa}}$ & 0.406 \\
\hline & & WT & $8.21^{\circ}$ & $9.49^{b c}$ & $10.43^{\mathrm{ab}}$ & $10.53^{\mathrm{Bab}}$ & $11.09^{\mathrm{Ba}}$ & 0.326 \\
\hline & & SEM & 0.367 & 0.456 & 0.302 & 0.421 & 0.258 & \\
\hline \multirow{3}{*}{\multicolumn{2}{|c|}{ Cooking loss }} & $\mathrm{CT}$ & 26.34 & 29.45 & 29.39 & 27.34 & 25.56 & 1.151 \\
\hline & & WT & 29.33 & 29.73 & 29.88 & 28.38 & 28.11 & 1.417 \\
\hline & & SEM & 1.863 & 0.995 & 0.791 & 1.349 & 1.194 & \\
\hline \multirow{3}{*}{\multicolumn{2}{|c|}{ WHC }} & $\mathrm{CT}$ & 54.14 & 58.56 & 56.58 & 54.24 & 54.90 & 2.211 \\
\hline & & WT & 53.23 & 57.02 & 58.51 & 54.81 & 57.74 & 1.945 \\
\hline & & SEM & 1.615 & 1.684 & 1.961 & 1.698 & 3.083 & \\
\hline
\end{tabular}

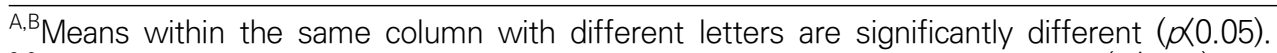

${ }^{a-c}$ Means within the same row with different letters are significantly different $(p<0.05)$.

CT, chicken thigh meat from conventional farm; WT, chicken thigh meat from animal welfare farm. 
저장 기간 동안 두 처리구 간 보수력(53.23\%-58.56\%)의 유의 적인 차이는 없었으며, 저장 기간 경과에 따른 유의적인 차이 는 없었다( $p>0.05)$. Wang 등(2009)의 연구에서는 방목된 육계 가슴육과 실내에서 사육된 육계 가슴육의 보수력의 차이는 없 었다고 보고하였으며, 사육 환경은 식육의 보수력에 영향을 미 치지 않았다고 보고하였다. Kim 등(2018)은 Arbor Acres종 일 반육계와 동물복지 육계 다리육의 경우, 냉장저장기간이 경과 함에 따라 보수력의 차이는 없었다고 보고하여 본 연구결과와 유사하였다.

\section{전단력}

국내 일반 및 동물복지 육계 다리육의 냉장 저장 기간 중 전 단력의 변화는 Table 4 에 나타내었다. 전단력은 고기의 선호도, 풍미 및 조리된 고기의 연도와 관련 있는 지표이며(Beilken et al., 1986), 전단력은 고기의 연하기를 평가하는 데 가장 효과적 인 방법으로 사용되고 있다(Kim et al., 2019). 모든 저장 일차 에서 CT보다 WT 처리구에서 유의적으로 높은 전단력 값을 나 타내었으며, 저장 기간이 증가함에 따라 전단력 값은 감소하였 다 $(p<0.05)$. Farmer 등(1997)과 Kim 등(2021)의 연구 결과도 사육밀도가 낮은 육계의 가슴육의 경우 높은 밀도로 사육된 육 계보다 높은 전단력 값을 보였다고 하여 본 연구와 동일한 경
향을 나타내었다. Castellini 등(2002)은 더 많은 운동을 할 수 있는 유기농 사육 환경에서 사육된 육계 다리육에서 일반 농장 에서 사육된 육계 다리육보다 더 높은 전단력 값에 영향을 미 쳤다고 보고하였다. 하지만, Schilling 등(2008)의 연구는 $45 \mathrm{~N}$ 미만의 닭고기는 소비자에게 연하다고 인식을 준다고 보고하 여, 육계보다 전단력이 높았지만 동물복지 닭 다리육도 연한 범주에 속한다고 판단된다. 또한 저장 기간이 증가함에 따라 감소한 전단력 값은 저장 중 효소 및 미생물이 생장하는 과정 중 발생하는 단백질 분해로 인한 것으로 사료된다(Kruk et al., 2011).

\section{미생물}

국내 일반 및 동물복지 육계 다리육의 저장 기간 중 총균수 와 대장균군의 변화는 Table 5 에 나타내었다. 일반 및 동물복지 육계 다리육의 초기 총균수는 2.54-2.58 Log CFU/g이었으며, 저장 5 일차까지 처리구 간의 유의적인 차이를 보이지 않았으나 ( $p>0.05)$, 저장 7,9 일차에 WT 처리구가 CT 처리구보다 유의 적으로 낮은 총균수를 나타내었다 $(p<0.05)$. 또한 식품의약품안 전처(MFDS, 2018)의 식육 중 미생물 권장 기준에서는 식육 판 매장에서 판매할 수 있는 닭고기의 총균수를 약 $6.7 \mathrm{Log}$ $\mathrm{CFU} / \mathrm{g}\left(5 \times 10^{6} \mathrm{CFU} / \mathrm{g}\right)$ 이하로 권장하고 있으나, 저장 9일차에

Table 4. Shear force $(\mathrm{N})$ of chicken thigh meat from conventional and animal welfare farm during cold storage

\begin{tabular}{ccccccc}
\hline \multirow{2}{*}{ Treatment } & \multicolumn{5}{c}{ Storage (days) } & \multirow{2}{*}{ SEM } \\
\cline { 2 - 5 } & 1 & 3 & 5 & 7 & 9 & 0.615 \\
CT & $21.18^{\mathrm{Ba}}$ & $21.27^{\mathrm{Ba}}$ & $18.34^{\mathrm{Bb}}$ & $15.86^{\mathrm{Bb}}$ & $12.35^{\mathrm{Bc}}$ & 0.601 \\
WT & $24.75^{\mathrm{Aa}}$ & $23.24^{\mathrm{Aa}}$ & $22.21^{\mathrm{Aab}}$ & $20.29^{\mathrm{Ab}}$ & $19.96^{\mathrm{Ab}}$ & 0.536 \\
SEM & 0.685 & 0.324 & 0.386 & 0.916 & 0.516 & \\
\hline
\end{tabular}

$\mathrm{A}, \mathrm{B}$ Means within the same column with different letters are significantly different $(\rho<0.05)$.

${ }^{a-c}$ Means within the same row with different letters are significantly different $(\not<0.05)$.

$\mathrm{CT}$, chicken thigh meat from conventional farm; WT, chicken thigh meat from animal welfare farm.

Table 5. Microorganisms (Log CFU/g) of chicken thigh meat from conventional and animal welfare farm during cold storage

\begin{tabular}{cccccccc}
\hline \multirow{2}{*}{ Items } & \multirow{2}{*}{ Treatment } & \multicolumn{7}{c}{ Storage (days) } & \multirow{2}{*}{ SEM } \\
\cline { 3 - 6 } & & 1 & 3 & 5 & 7 & 9 & \\
\hline Total aerobic & $\mathrm{CT}$ & $2.58^{\mathrm{d}}$ & $2.71^{\mathrm{d}}$ & $3.81^{\mathrm{C}}$ & $6.26^{\mathrm{Ab}}$ & $6.99^{\mathrm{Aa}}$ & 0.098 \\
bacteria & $\mathrm{WT}$ & $2.54^{\mathrm{d}}$ & $2.66^{\mathrm{d}}$ & $3.68^{\mathrm{C}}$ & $5.45^{\mathrm{Bb}}$ & $6.22^{\mathrm{Ba}}$ & 0.091 \\
& $\mathrm{SEM}$ & 0.099 & 0.081 & 0.088 & 0.104 & 0.099 & \\
\hline Coliforms & $\mathrm{CT}$ & $\mathrm{ND}$ & $\mathrm{ND}$ & $\mathrm{ND}$ & 1.31 & 1.43 & 0.156 \\
& $\mathrm{WT}$ & $\mathrm{ND}$ & $\mathrm{ND}$ & $\mathrm{ND}$ & 1.27 & 1.32 & 0.142 \\
& $\mathrm{SEM}$ & & & & 0.140 & 0.159 & \\
\hline
\end{tabular}

$\overline{A, B}$ Means within the same column with different letters are significantly different $(\rho<0.05)$.

${ }^{a-d}$ Means within the same row with different letters are significantly different $(\alpha<0.05)$.

$\mathrm{CT}$, chicken thigh meat from conventional farm; WT, chicken thigh meat from animal welfare farm; ND, not detected. 
$\mathrm{CT}$ 처리구는 기준을 초과하였다. 대장균군의 경우, 저장 5 일차 까지 검출되지 않았으나, 7일차부터 검출되었으며, 처리구 간 의 유의적인 차이는 없었다 $(p>0.05)$. 대장균의 경우 모든 처리 구 및 저장일차에서 검출되지 않았다(데이터를 표시하지 않음). Wang 등(2019)은 고밀도로 사육된 계군 내에서 미생물이 쉽게 전파될 수 있으며, 육계 식육에서 발생하는 미생물은 도축장에 서 도계하는 동안 육계의 분변에나 환경에서 닭고기를 오염시 킬 수 있다고 보고하였다. Patria 등(2016)은 육계 가슴육의 호 기성 미생물 수는 고밀도에서 사육된 육계보다 저밀도에서 사 육된 육계에서 높았다고 보고하였다.

\section{Thiobarbituric acid reactive substances(TBARS) 및 volatile basic nitrogen(VBN)}

국내 일반 및 동물복지 육계 다리육의 저장 기간 중 TBARS 변화 및 VBN 함량은 Table 6에 나타내었다. TBARS는 지질의 산화 수준을 나타내며, 말론 알데하이드, 케톤 및 유사한 지질 산화물을 측정한다. 두 처리구 모두 저장기간이 증가함에 따라 TBARS값이 유의적으로 증가하였으며 $(p<0.05)$, 모든 저장 일 차에서 $\mathrm{WT}$ 가 $\mathrm{CT}$ 보다 유의적으로 낮은 $\mathrm{MDA}$ 함량을 나타내었 다 $(p<0.05)$. 이는 동물복지육계가 일반육계보다 지방산패가 다 소 지연됨을 보인 것으로 판단된다. Husak 등(2008)의 연구는 다리육 TBARS 값은 방목된 육계 $(0.12 \mathrm{MDA} \mathrm{mg} / \mathrm{kg})$ 가 일반적 으로 사육된 육계 $(0.18 \mathrm{MDA} \mathrm{mg} / \mathrm{kg})$ 보다 유의적으로 낮은 값 을 나타내어 본 연구 결과와 유사하였다.

VBN 함량은 식육의 신선도를 판단하는 지표로 사용되고 있 으며, 우리나라 식품공전의 신선육 기준은 $20 \mathrm{mg} / 100 \mathrm{~g}$ 이하로 판정하고 있다(MFDS, 2018). VBN 분석 결과, 두 처리구 모두 저장 기간에 따라 유의적으로 증가하였으며, 저장 $1,3,7$ 일차 에는 두 처리구 간의 유의적인 차이를 보이지 않았으나 $(p>0.05)$, 저장 5,9 일차에는 WT가 CT보다 유의적으로 높은
함량을 나타내었다( $p<0.05)$. Jung 등(2010)은 식육 내 효소 및 미생물이 식육 단백질 분해를 증가시켜 아미노산과 $\mathrm{VBN}$ 함량 을 증가시킨다고 보고하였다. 본 연구결과, 저장 기간에 따른 총균수의 증가로 인하여 VBN 함량이 증가한 것으로 사료된다.

\section{지방산 조성}

국내 일반 및 동물복지 육계 다리육의 저장 기간 중 지방산 함량의 변화는 Table 7에 나타내었다. 다리육의 주요 지방산은 oleic acid(40.12\%-38.17\%), palmitic acid(23.61\%-24.97\%), linoleic $\operatorname{acid}(17.06 \%-18.79 \%)$ 이었으며, myristic acid 함량은 1, 3, 5, 9 일차에서 동물복지육계 닭다리육이 일반농장육계 닭다리육보 다 높은 함량을 나타내었다 $(p<0.05)$. Ahmed 등(2015)의 연구 에서도 닭 다리육의 주요 지방산은 oleic $\operatorname{acid}(39.18 \%-43.06 \%)$, palmitic acid(22.91\%-25.04\%), linoleic $\operatorname{acid}(14.01 \%-15.59 \%)$ 로 본 연구와 유사한 수치를 나타내었다. Küçükyilmaz 등(2012)의 결과에서는 닭 다리육의 SFA, MUFA, PUFA 함량은 일반적으 로 사육된 닭(Hubbard Red-JA)과 유기농으로 사육된 닭 (Hubbard Red-JA)에서 유의적인 차이를 보이지 않았다고 보고 하여 본 연구결과와 유사하였다.

생리활성물질(creatine, creatinine, anserine, carnosine)

국내 일반 및 동물복지 육계 다리육의 저장 기간 중 creatine, creatinine 및 di-peptide(anserine 및 carnosine)의 변화는 Table 8에 나타내었다. Creatine, creatinine 및 di-peptide(anserine 및 carnosine)의 생리 활성 물질은 척추 동물의 골격근에 함유되어 있으며, 육류 섭취를 통해서만 섭취할 수 있다(Schmid, 2009). Creatine과 creatinine은 신경 보호 효과를 가지고 있으며, dipeptide(anserine 및 carnosine)은 금속 킬레이터 효과와 유리 라 디칼 소거제 역할로 항산화 기능을 가지고 있다(Boldyrev and Severin, 1990). Creatine, creatinine, anserine, carnosine 함량은

Table 6. TBARS (mg MDA $/ \mathrm{kg}$ ) and VBN $(\mathrm{mg} / 100 \mathrm{~g}$ ) of chicken thigh meat from conventional and animal welfare farm during cold storage

\begin{tabular}{cccccccc}
\hline \multirow{2}{*}{ Items } & Treatment & \multicolumn{7}{c}{ Storage (days) } & \multirow{2}{*}{ SEM } \\
\cline { 3 - 6 } & & 1 & 3 & 5 & 7 & 9 & \\
\hline \multirow{2}{*}{ TBARS } & $\mathrm{CT}$ & $0.20^{\mathrm{Ae}}$ & $0.24^{\mathrm{Ad}}$ & $0.27^{\mathrm{Ac}}$ & $0.32^{\mathrm{Ab}}$ & $0.37^{\mathrm{Aa}}$ & 0.006 \\
& $\mathrm{WT}$ & $0.13^{\mathrm{Bd}}$ & $0.16^{\mathrm{Bc}}$ & $0.18^{\mathrm{Bc}}$ & $0.21^{\mathrm{Bb}}$ & $0.27^{\mathrm{Ba}}$ & 0.005 \\
& $\mathrm{SEM}$ & 0.004 & 0.004 & 0.007 & 0.007 & 0.003 & \\
\hline VBN & $\mathrm{CT}$ & $8.28^{\mathrm{e}}$ & $9.52^{\mathrm{d}}$ & $10.87^{\mathrm{Ac}}$ & $14.53^{\mathrm{b}}$ & $27.83^{\mathrm{Aa}}$ & 0.163 \\
& WT & $8.21^{\mathrm{e}}$ & $9.08^{\mathrm{d}}$ & $10.35^{\mathrm{Bc}}$ & $14.17^{\mathrm{b}}$ & $26.08^{\mathrm{Ba}}$ & 0.155 \\
& SEM & 0.166 & 0.163 & 0.127 & 0.185 & 0.147 & \\
\hline
\end{tabular}

\footnotetext{
$\overline{A, B}$ Means within the same column with different letters are significantly different $(\not<0.05)$.

${ }^{a-e}$ Means within the same row with different letters are significantly different $(\phi<0.05)$.

TBARS, thiobarbituric acid reactive substances; CT, chicken thigh meat from conventional farm; WT, chicken thigh meat from animal welfare farm; VBN, volatile basic nitrogen.
} 
Table 7. Fatty acid composition (\%) of chicken thigh meat from conventional and animal welfare farm during cold storage

\begin{tabular}{|c|c|c|c|c|c|c|c|}
\hline \multirow{2}{*}{ Items } & \multirow{2}{*}{ Treatment } & \multicolumn{5}{|c|}{ Storage $(d)$} & \multirow{2}{*}{ SEM } \\
\hline & & 1 & 3 & 5 & 7 & 9 & \\
\hline \multirow{3}{*}{$\begin{array}{c}\text { C14:0 } \\
\text { (Myristic acid) }\end{array}$} & CT & $0.56^{\mathrm{Bb}}$ & $0.60^{\mathrm{Bb}}$ & $0.59^{B b}$ & $0.97^{a}$ & $0.62^{\mathrm{Bb}}$ & 0.016 \\
\hline & WT & $0.95^{\mathrm{A}}$ & $0.95^{\mathrm{A}}$ & $0.95^{\mathrm{A}}$ & 0.82 & $0.92^{\mathrm{A}}$ & 0.041 \\
\hline & SEM & 0.013 & 0.014 & 0.012 & 0.061 & 0.025 & \\
\hline \multirow{3}{*}{$\begin{array}{c}\text { C16:0 } \\
\text { (Palmitic acid) }\end{array}$} & CT & $23.61^{b}$ & $23.81^{\mathrm{Bb}}$ & $23.65^{b}$ & $24.35^{\mathrm{ab}}$ & $24.97^{a}$ & 0.220 \\
\hline & WT & 24.04 & $24.52^{\mathrm{A}}$ & 23.92 & 24.21 & 24.32 & 0.183 \\
\hline & SEM & 0.239 & 0.176 & 0.237 & 0.124 & 0.213 & \\
\hline \multirow{3}{*}{$\begin{array}{c}\text { C16:1n7 } \\
\text { (Palmitoleic acid) }\end{array}$} & $\mathrm{CT}$ & 6.21 & $6.74^{\mathrm{A}}$ & 6.48 & 6.30 & $6.79^{\mathrm{A}}$ & 0.180 \\
\hline & WT & 6.10 & $6.27^{\mathrm{B}}$ & 5.88 & 6.17 & $6.16^{\mathrm{B}}$ & 0.148 \\
\hline & SEM & 0.174 & 0.058 & 0.178 & 0.249 & 0.088 & \\
\hline \multirow{3}{*}{$\begin{array}{c}\text { C18:0 } \\
\text { (Stearic acid) }\end{array}$} & CT & $6.35^{\mathrm{B}}$ & 6.14 & 6.27 & 6.51 & 6.51 & 0.131 \\
\hline & WT & $6.76^{\mathrm{Aab}}$ & $6.58^{\mathrm{ab}}$ & $6.50^{\mathrm{ab}}$ & $6.36^{b}$ & 6.83 & 0.096 \\
\hline & SEM & 0.098 & 0.116 & 0.068 & 0.123 & 0.151 & \\
\hline \multirow{3}{*}{$\begin{array}{l}\text { C18:1n9 } \\
\text { (Oleic acid) }\end{array}$} & CT & $40.12^{a}$ & $39.35^{\mathrm{ab}}$ & $39.24^{\mathrm{ab}}$ & $38.94^{\mathrm{ab}}$ & $38.17^{b}$ & 0.393 \\
\hline & WT & 39.01 & 39.60 & 40.09 & 39.61 & 39.43 & 0.326 \\
\hline & SEM & 0.439 & 0.149 & 0.176 & 0.531 & 0.353 & \\
\hline \multirow{3}{*}{$\begin{array}{c}\text { C18:1n7 } \\
\text { (Vaccenic acid) }\end{array}$} & CT & 2.31 & 2.31 & 2.19 & 2.22 & 2.17 & 0.079 \\
\hline & WT & 2.42 & 2.36 & 2.34 & 2.24 & 2.25 & 0.065 \\
\hline & SEM & 0.057 & 0.056 & 0.053 & 0.052 & 0.120 & \\
\hline \multirow{3}{*}{$\begin{array}{c}\text { C18:2n6 } \\
\text { (Linoleic acid) }\end{array}$} & CT & 17.94 & $18.29^{A}$ & $18.79^{A}$ & 17.92 & 18.07 & 0.214 \\
\hline & WT & 17.69 & $17.06^{\mathrm{B}}$ & $17.66^{\mathrm{B}}$ & 18.07 & 17.47 & 0.359 \\
\hline & SEM & 0.452 & 0.164 & 0.208 & 0.303 & 0.267 & \\
\hline \multirow{3}{*}{$\begin{array}{c}\text { C18:3n6 } \\
(\gamma-\text { Linolenic acid })\end{array}$} & $\mathrm{CT}$ & 0.18 & 0.20 & 0.18 & 0.22 & $0.19^{\mathrm{A}}$ & 0.020 \\
\hline & WT & 0.17 & 0.16 & 0.15 & 0.17 & $0.15^{B}$ & 0.007 \\
\hline & SEM & 0.011 & 0.013 & 0.017 & 0.024 & 0.003 & \\
\hline \multirow{3}{*}{$\begin{array}{c}\text { C18:3n3 } \\
\text { (Linolenic acid) }\end{array}$} & CT & 0.82 & 0.83 & 0.86 & $0.91^{A}$ & $0.81^{B}$ & 0.026 \\
\hline & WT & 0.86 & 0.86 & 0.90 & $0.83^{\mathrm{B}}$ & $0.90^{\mathrm{A}}$ & 0.017 \\
\hline & SEM & 0.035 & 0.019 & 0.014 & 0.017 & 0.019 & \\
\hline \multirow{3}{*}{$\begin{array}{c}\text { C20:1n9 } \\
\text { (Eicosenoic acid) }\end{array}$} & CT & 0.22 & 0.20 & 0.22 & 0.22 & 0.22 & 0.011 \\
\hline & WT & 0.24 & 0.20 & 0.23 & 0.22 & 0.23 & 0.009 \\
\hline & SEM & 0.009 & 0.005 & 0.008 & 0.013 & 0.014 & \\
\hline \multirow{3}{*}{$\begin{array}{c}\text { C20:4n6 } \\
\text { (Arachidonic acid) }\end{array}$} & $\mathrm{CT}$ & 1.17 & 1.07 & 1.01 & 0.88 & 0.90 & 0.077 \\
\hline & WT & $1.23^{\mathrm{a}}$ & $0.99^{\mathrm{ab}}$ & $0.90^{\mathrm{b}}$ & $0.87^{b}$ & $0.84^{b}$ & 0.067 \\
\hline & SEM & 0.061 & 0.097 & 0.070 & 0.027 & 0.085 & \\
\hline \multirow{3}{*}{$\begin{array}{c}\mathrm{C} 20: 5 \mathrm{n} 3 \\
\text { (Eicosapentaenoic acid) }\end{array}$} & $\mathrm{CT}$ & $0.09^{\mathrm{ab}}$ & $0.08^{b}$ & $0.09^{\mathrm{ab}}$ & $0.15^{\mathrm{ab}}$ & $0.16^{\mathrm{a}}$ & 0.017 \\
\hline & WT & $0.11^{\mathrm{ab}}$ & $0.07^{b}$ & $0.11^{\mathrm{ab}}$ & $0.11^{\mathrm{ab}}$ & $0.15^{\mathrm{a}}$ & 0.016 \\
\hline & SEM & 0.020 & 0.004 & 0.011 & 0.020 & 0.020 & \\
\hline \multirow{3}{*}{$\begin{array}{c}\text { C22:4n6 } \\
\text { (Adrenic acid) }\end{array}$} & CT & 0.27 & 0.24 & 0.22 & 0.23 & 0.24 & 0.026 \\
\hline & WT & 0.27 & 0.24 & 0.22 & 0.20 & 0.23 & 0.016 \\
\hline & SEM & 0.027 & 0.027 & 0.017 & 0.011 & 0.019 & \\
\hline \multirow{3}{*}{$\begin{array}{c}\text { C22:6n3 } \\
\text { (Docosahexaenoic acid) }\end{array}$} & $\mathrm{CT}$ & 0.14 & 0.14 & $0.18^{A}$ & 0.18 & $0.18^{A}$ & 0.010 \\
\hline & WT & 0.16 & 0.14 & $0.14^{\mathrm{B}}$ & 0.14 & $0.14^{\mathrm{B}}$ & 0.016 \\
\hline & SEM & 0.017 & 0.013 & 0.011 & 0.015 & 0.009 & \\
\hline
\end{tabular}


Table 7. Continued.

\begin{tabular}{|c|c|c|c|c|c|c|c|}
\hline \multirow{2}{*}{ Items } & \multirow{2}{*}{ Treatment } & \multicolumn{5}{|c|}{ Storage $(d)$} & \multirow{2}{*}{ SEM } \\
\hline & & 1 & 3 & 5 & 7 & 9 & \\
\hline \multirow[t]{3}{*}{ SFA } & CT & 30.52 & $30.55^{\mathrm{B}}$ & 30.52 & $31.83^{\mathrm{A}}$ & 32.10 & 0.237 \\
\hline & WT & 31.75 & $32.04^{\mathrm{A}}$ & 31.37 & $31.39^{B}$ & 32.07 & 0.226 \\
\hline & SEM & 0.320 & 0.157 & 0.272 & 0.038 & 0.256 & \\
\hline \multirow[t]{3}{*}{ USFA } & $\mathrm{CT}$ & 69.48 & $69.45^{A}$ & 69.48 & $68.17^{B}$ & 67.90 & 0.237 \\
\hline & WT & 68.25 & $67.96^{\mathrm{B}}$ & 68.63 & $68.61^{\mathrm{A}}$ & 67.93 & 0.226 \\
\hline & SEM & 0.320 & 0.157 & 0.272 & 0.038 & 0.256 & \\
\hline \multirow[t]{3}{*}{ PUFA } & $\mathrm{CT}$ & 20.61 & $20.85^{A}$ & 21.34 & 20.48 & 20.56 & 0.249 \\
\hline & WT & 20.49 & $19.53^{B}$ & $20.09^{B}$ & 20.38 & 19.87 & 0.433 \\
\hline & SEM & 0.531 & 0.101 & 0.236 & 0.375 & 0.367 & \\
\hline \multirow[t]{3}{*}{ MUFA } & $\mathrm{CT}$ & $48.87^{a}$ & $48.60^{\mathrm{ab}}$ & $48.14^{\mathrm{ab}}$ & $47.69^{\mathrm{ab}}$ & $47.34^{b}$ & 0.326 \\
\hline & WT & 47.76 & 48.43 & 48.55 & 48.23 & 48.07 & 0.329 \\
\hline & SEM & 0.546 & 0.105 & 0.228 & 0.344 & 0.237 & \\
\hline \multirow[t]{3}{*}{ W3/W6 } & $\mathrm{CT}$ & $0.65^{b}$ & $0.71^{\mathrm{ab}}$ & $0.81^{\mathrm{ab}}$ & $0.92^{\mathrm{a}}$ & $0.87^{\mathrm{ab}}$ & 0.054 \\
\hline & WT & $0.68^{b}$ & $0.78^{\mathrm{ab}}$ & $0.90^{\mathrm{ab}}$ & $0.88^{\mathrm{ab}}$ & $0.99^{\mathrm{a}}$ & 0.049 \\
\hline & SEM & 0.033 & 0.065 & 0.053 & 0.035 & 0.061 & \\
\hline
\end{tabular}

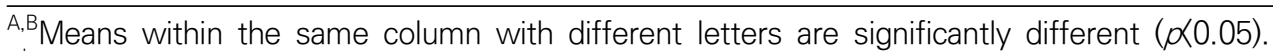

${ }^{a, b}$ Means within the same row with different letters are significantly different $(\rho<0.05)$.

$\mathrm{CT}$, chicken thigh meat from conventional farm, WT, chicken thigh meat from animal welfare farm.

Table 8. Creatine, creatinine and di-peptide $(\mathrm{mg} / 100 \mathrm{~g})$ contents of chicken thigh meat from conventional and animal welfare farm during cold storage

\begin{tabular}{cccccccc}
\hline \multirow{2}{*}{ Items } & Treatment & \multicolumn{7}{c}{ Storage $(\mathrm{d})$} & \multirow{2}{*}{ SEM } \\
\cline { 3 - 6 } Creatine & CT & 337.01 & 333.06 & 351.02 & 337.24 & 327.31 & 13.806 \\
& WT & $367.85^{\mathrm{a}}$ & $352.56^{\mathrm{ab}}$ & $338.85^{\mathrm{abc}}$ & $315.34^{\mathrm{c}}$ & $331.39^{\mathrm{bc}}$ & 6.912 \\
& SEM & 10.023 & 8.070 & 11.537 & 13.073 & 11.241 & \\
\hline Creatinine & CT & 3.09 & 3.34 & 3.81 & 3.54 & 3.54 & 0.205 \\
& WT & $2.94^{\mathrm{b}}$ & $3.60^{\mathrm{ab}}$ & $3.92^{\mathrm{a}}$ & $3.27^{\mathrm{ab}}$ & $3.87^{\mathrm{a}}$ & 0.162 \\
& SEM & 0.144 & 0.161 & 0.291 & 0.153 & 0.130 & \\
\hline Anserine & CT & $124.34^{\mathrm{a}}$ & $117.86^{\mathrm{ab}}$ & $112.90^{\mathrm{ab}}$ & $99.31^{\mathrm{ab}}$ & $85.81^{\mathrm{b}}$ & 7.660 \\
& WT & $141.49^{\mathrm{a}}$ & $125.81^{\mathrm{ab}}$ & $120.69^{\mathrm{ab}}$ & $129.44^{\mathrm{ab}}$ & $110.56^{\mathrm{b}}$ & 5.357 \\
& SEM & 6.712 & 7.781 & 4.641 & 7.515 & 5.902 & \\
\hline Carnosine & CT & $53.75^{\mathrm{ab}}$ & $67.29^{\mathrm{a}}$ & $62.54^{\mathrm{ab}}$ & $45.20^{\mathrm{bc}}$ & $32.09^{\mathrm{c}}$ & 4.726 \\
& WT & 52.28 & 54.42 & 59.18 & 48.68 & 45.03 & 5.933 \\
& SEM & 4.671 & 4.949 & 6.965 & 5.393 & 4.465 & \\
\hline
\end{tabular}

${ }^{a-c}$ Means within the same row with different letters are significantly different $(\not<0.05)$.

$\mathrm{CT}$, chicken thigh meat from conventional farm; WT, chicken thigh meat from animal welfare farm.

모든 저장기간 동안 처리구 간의 유의적인 차이를 보이지 않았 다 $(p>0.05)$. WT 처리구에서 creatine 함량은 저장 기간이 경과함 에 따라 감소하는 경향을 나타내었으나( $p<0.05)$, creatinine은 두
처리구 모두 저장 기간에 따라 증가하는 경향을 나타내었다 $(p<0.05)$. Anserine함량은 두 처리구 모두 저장 기간이 경과함 에 따라 감소하는 경향을 나타내었으며 $(p<0.05)$, carnosine 함 
Table 9. DPPH, FRAP, ABTS, and ORAC activities ( $\mu \mathrm{M} \mathrm{TE} / \mathrm{mg}$ dry matter) of chicken thigh meat from conventional and animal welfare farm during cold storage

\begin{tabular}{|c|c|c|c|c|c|c|c|}
\hline \multirow{2}{*}{ Items } & \multirow{2}{*}{ Treatment } & \multicolumn{5}{|c|}{ Storage $(\mathrm{d})$} & \multirow{2}{*}{ SEM } \\
\hline & & 1 & 3 & 5 & 7 & 9 & \\
\hline \multirow[t]{3}{*}{ DPPH } & $\mathrm{CT}$ & $16.59^{a}$ & $13.65^{\mathrm{ab}}$ & $11.57^{\mathrm{bc}}$ & $9.87^{\circ}$ & $9.25^{c}$ & 0.737 \\
\hline & WT & $18.45^{a}$ & $16.31^{\mathrm{ab}}$ & $13.10^{b c}$ & $10.82^{c}$ & $9.62^{\circ}$ & 1.164 \\
\hline & SEM & 1.287 & 0.822 & 0.980 & 1.038 & 0.607 & \\
\hline \multirow[t]{3}{*}{ ABTS } & CT & $97.00^{\mathrm{a}}$ & $94.14^{a}$ & $96.43^{a}$ & $92.86^{a}$ & $84.57^{b}$ & 1.556 \\
\hline & WT & $99.00^{\mathrm{a}}$ & $94.71^{b}$ & $94.71^{b}$ & $94.00^{b}$ & $87.14^{c}$ & 0.753 \\
\hline & SEM & 0.627 & 0.821 & 0.926 & 1.626 & 1.706 & \\
\hline \multirow[t]{3}{*}{ FRAP } & $\mathrm{CT}$ & $11.41^{\mathrm{Bab}}$ & $12.03^{\mathrm{a}}$ & $9.80^{\mathrm{bc}}$ & $8.43^{c}$ & $7.85^{\mathrm{c}}$ & 0.490 \\
\hline & WT & $15.31^{\mathrm{Aa}}$ & $12.12^{b}$ & $9.55^{\mathrm{bc}}$ & $9.35^{\mathrm{c}}$ & $8.13^{c}$ & 0.644 \\
\hline & SEM & 0.769 & 0.647 & 0.478 & 0.526 & 0.350 & \\
\hline \multirow[t]{3}{*}{ ORAC } & CT & $195.91^{\mathrm{a}}$ & $169.22^{\mathrm{Bab}}$ & $152.44^{\mathrm{bc}}$ & $149.44^{\mathrm{bc}}$ & $131.24^{c}$ & 8.799 \\
\hline & WT & $203.71^{\mathrm{a}}$ & 197.88 Aab & $168.32^{\mathrm{bc}}$ & $155.32^{c}$ & $142.09^{c}$ & 7.064 \\
\hline & SEM & 3.400 & 7.941 & 7.518 & 10.368 & 8.925 & \\
\hline
\end{tabular}

A,B Means within the same column with different letters are significantly different $(p<0.05)$.

${ }^{a-c}$ Means within the same row with different letters are significantly different $(\not<0.05)$.

FRAP, ferric reducing antioxidant power; ORAC, oxygen radical absorbance capacity; CT, chicken thigh meat from conventional farm, WT, chicken thigh meat from animal welfare farm.

량은 CT에서만 유의적으로 감소하였다 $(p<0.05) . \mathrm{Kim}$ 등(2018)의 연구에서는 동물복지 육계 다리육과 일반 육계 다리육의 creatine 과 carnosine 함량 차이가 없었다고 보고하였으며, anserine 함량 은 동물복지 육계에서 유의적으로 높은 값을 나타내었다.

\section{항산화 활성}

국내 일반 및 동물복지 육계 다리육의 저장 기간 중 $\mathrm{DPPH}$ 라디칼 소거능, $\mathrm{ABTS}$ 라디칼 소거능, $\mathrm{FRAP}, \mathrm{ORAC}$ 활성의 변 화는 Table 9에 나타내었다. DPPH 및 ABTS 라디칼 소거능은 물질 내 특성 항산화 물질이 라디칼을 억제하는 작용의 원리를 이용하여 측정하는 방법으로 사용되고 있으며, FARP 활성은 환원력을 이용하여 측정한다. ORAC 활성은 라디칼 소거능을 이용하는 방법이지만, 다른 항산화 활성에 비해 반응 감도가 예민하며, 정확도가 높은 방법으로 알려져 있다(Kim et al., 2013). DPPH 라디칼 소거능, ABTS 라디칼 소거능과 ORAC 활성은 처리구 간의 유의적인 차이를 보이지 않았으나 $(p>0.05)$, $\mathrm{FRAP}$ 활성 결과에서 저장 1 일차에 $\mathrm{WB}$ 가 $\mathrm{CB}$ 보다 유의적으로 높은 활성을 나타내었다 $(p<0.05)$. 또한 $\mathrm{DPPH}$ 라디칼 소거능, $\mathrm{ABTS}$ 라디칼 소거능, FRAP 활성과 $\mathrm{ORAC}$ 활성 모두 저장 기 간이 경과함에 따라 유의적으로 항산화 활성이 감소하였다 $(p<0.05) . \mathrm{Kim}$ and Jang(2021)은 소고기 등심과 우둔을 $4 \pm 1^{\circ} \mathrm{C}$ 의 온도에서 저장하여 $\mathrm{DPPH}$ 라디칼 소거능, $\mathrm{ABTS}$ 라디칼 소거능, FRAP 활성을 측정하였으며, 모든 항목에서 저장 기간이 경과함
에 따라 유의적으로 감소하여 본 연구 결과와 유사하였다.

\section{요약}

본 연구는 동물복지육계(Cobb) 다리육을 냉장저장하면서 이 화학적 특성과 생리활성물질의 변화를 규명하기 위해 실시하 였다. 일반육계 $(\mathrm{n}=30)$ 와 동물복지육계 $(\mathrm{n}=30)$ 를 도계 후 랩포장 하여 $4 \pm 1^{\circ} \mathrm{C}$ 저온 인큐베이터에서 저장하면서 $1,3,5,7,9$ 일에 각각 이화학적 품질특성과 생리활성기능성분의 변화를 측정하 였다. 일반성분조성의 차이는 없었으며 적색도를 나타내는 $\mathrm{a}^{*}$ 값은 두 처리구 모두 저장기간에 따른 유의적인 차이를 보이지 않았다. 모든 저장 일차에서 일반농장육계보다 동물복지육계에 서 유의적으로 높은 전단력을 나타내었다. 미생물의 경우, 저장 7, 9일차에 WT 처리구가 CT 처리구보다 유의적으로 낮은 총 균수를 나타내었다. 지방산패도의 경우, 모든 저장 일차에서 WT가 CT보다 유의적으로 낮은 TBARS 함량을 나타내었다. 생리활성물질인 creatine, creatinine, anserine, carnosine 함량은 모든 저장기간 동안 처리구 간의 유의적인 차이를 보이지 않았 다. 따라서 본 연구결과, 동물복지 Cobb종 육계 다리육은 일반 육계보다 저장 7일 이후 낮은 미생물수준과 지방산패도 및 높은 전단력을 나타내는 차이가 있는 것으로 판단되며, 이후 지속적 인 동물복지육계의 품질 모니터링이 필요할 것으로 판단된다.

\section{Conflicts of Interest}

The authors declare no potential conflict of interest. 


\section{Acknowledgments}

This work was supported by the Korea Institute of Planning and Evaluation for Technology in Food, Agriculture and Forestry (IPET) through Agri-Bio industry Technology Development Program, funded by Ministry of Agriculture, Food and Rural Affairs (MAFRA) (318022041HD030).

\section{Ethics Approval}

This article does not require IRB/IACUC approval because there are no human and animal participants.

\section{Author Contributions}

Conceptualization: Kim Hee-Jin, Kim D, Jang A.

Data curation: Kim Hee-Jin, Kim D, Kim Hye-Jin.

Formal analysis: Kim Hee-Jin, Kim D, Kim Hye-Jin.

Methodology: Kim Hee-Jin, Kim D, Kim Hye-Jin.

Software: Kim Hee-Jin, Kim D, Kim Hye-Jin, Kwon JS.

Validation: Jang A.

Investigation: Kim Hee-Jin, Kim D, Kim Hye-Jin, Kwon JS. Writing - original draft: Kim Hee-Jin, Kim D, Kim Hye-Jin, Kwon JS, Jang A.

Writing - review \& editing: Kim Hee-Jin, Kim D, Kim Hye-Jin, Kwon JS, Jang A.

\section{Author Information}

Hee-Jin Kim (Postdoctor Researcher, Kangwon National University) https://orcid.org/0000-0002-6959-9790

Dongwook Kim (Researcher, Kangwon National University) https://orcid.org/0000-0002-5496-1961

Hye-Jin Kim (Graduate Student, Kangwon National University) https://orcid.org/0000-0002-9384-6720

Ji-Seon Kwon (Graduate Student, Kangwon National University) https://orcid.org/0000-0003-4885-6249

Aera Jang (Professor, Kangwon National University) https://orcid.org/0000-0003-1789-8956

\section{References}

Ahmed ST, Islam MM, Bostami ABMR, Mun HS, Kim YJ, Yang CJ. 2015. Meat composition, fatty acid profile and oxidative stability of meat from broilers supplemented with pomegranate (Punica granatum L.) by-products. Food Chem 188:481-488.

AOAC. 1995. Official methods of analysis. $6^{\text {th }}$ ed. Association of Official Analytical Chemists, Washington, DC, USA.

Beilken SL, Bouton PE, Harris PV. 1986. Some effects on the mechanical properties of meat produced by cooking at temperatures between $50^{\circ}$ and $60^{\circ} \mathrm{C}$. J Food Sci 51:791796.

Benzie IFF, Strain JJ. 1996. The ferric reducing ability of plasma (FRAP) as a measure of "antioxidant power": the FRAP assay. Anal Biochem 239:70-76.

Blois MS. 1958. Antioxidant determinations by the use of a stable free radical. Nature 181:1199-1200.

Boldyrev AA, Severin SE. 1990. The histidine-containing dipeptides, carnosine and anserine: distribution, properties and biological significance. Adv Enzyme Regul 30:175194.

Buege JA, Aust SD. 1978. Microsomal lipid peroxidation. Methods Enzymol 52:302-310.

Castellini C, Mugnai C, Dal Bosco A. 2002. Effect of organic production system on broiler carcass and meat quality. Meat Sci 60:219-225.

Choi YS, Choi JH, Han DJ, Kim HY, Lee MA, Kim HW, Jeong JY, Kim CJ. 2009. Characteristics of low-fat meat emulsion systems with pork fat replaced by vegetable oils and rice bran fiber. Meat Sci 82:266-271.

Farmer LJ, Perry GC, Lewis PD, Nute GR, Piggott JR, Patterson RLS. 1997. Responses of two genotypes of chicken to the diets and stocking densities of conventional $\mathrm{UK}$ and label rouge production systems. II. Sensory attributes. Meat Sci 47:77-93.

Folch J, Lees M, Stanley GHS. 1957. A simple method for the isolation and purification of total lipids from animal tissues. J Biol Chem 226:497-509.

Gillespie KM, Chae JM, Ainsworth EA. 2007. Rapid measurement of total antioxidant capacity in plants. Nat Protoc $2: 867-870$

Husak RL, Sebranek JG, Bregendahl K. 2008. A survey of commercially available broilers marketed as organic, freerange, and conventional broilers for cooked meat yields, meat composition, and relative value. Poult Sci 87:23672376.

Jay JM, Shelef LA. 1978. Microbial modifications in raw and processed meats and poultry at low temperatures. Food Technol 32:186-187.

Jeon JJ, Hong EC, Kang HK, Kim HS, Son J, You AS, Kim HJ, Kang BS. 2020. A review of footpad dermatitis charac- 
teristics, causes, and scoring system for broiler chickens. Korean J Poult Sci 47:199-210.

Jung S, Choe JH, Kim B, Yun H, Kruk ZA, Jo C. 2010. Effect of dietary mixture of gallic acid and linoleic acid on antioxidative potential and quality of breast meat from broilers. Meat Sci 86:520-526.

Kim D, Pak J, Chae HS, Kim YB, Jang A. 2013. Antioxidation effect of leg bone extracts and enzyme hydrolysates from Jeju crossbred horses (Jeju native horse $\times$ Thoroughbred). J Life Sci 23:1147-1154.

Kim HJ, Jang A. 2021. Correlations between the levels of the bioactive compounds and quality traits in beef loin and round during cold storage. Food Control 120:107491.

Kim HJ, Jeon JJ, Kim H, Son J, Kim KY, You AS, Hong EC, Kang B, Kang HK. 2021. Effects of stocking density on the growth performance, immune status and breast meat quality of broiler. Korean J Poult Sci 48:13-22.

Kim HJ, Kim HJ, Jeon JJ, Nam KC, Shim KS, Jung JH, Kim KS, Choi Y, Kim SH, Jang A. 2020. Comparison of the quality characteristics of chicken breast meat from conventional and animal welfare farms under refrigerated storage. Poult Sci 99:1788-1796.

Kim HJ, Kim HJ, Jeon JJ, Oh SJ, Nam KC, Shim KS, Jung JH, Kim KS, Choi YI, Kim SH, Jang A. 2018. Comparison of quality and bioactive compounds in chicken thigh meat from conventional and animal welfare farm in Korea. Korean J Poult Sci 45:261-272.

Kim HJ, Sujiwo J, Kim HJ, Jang A. 2019. Effects of dipping chicken breast meat inoculated with Listeria monocytogenes in lyophilized scallion, garlic, and kiwi extracts on its physicochemical quality. Food Sci Anim Resour 39:418429.

Kruk ZA, Yun H, Rutley DL, Lee EJ, Kim YJ, Jo C. 2011. The effect of high pressure on microbial population, meat quality and sensory characteristics of chicken breast fillet. Food Control 22:6-12.

Küçükyilmaz K, Bozkurt M, Çatli AU, Herken EN, Çinar M,
Bintaş E. 2012. Chemical composition, fatty acid profile and colour of broiler meat as affected by organic and conventional rearing systems. S Afr J Anim Sci 42:360368.

Ministry of Food and Drug Safety [MFDS]. 2018. Food code. Available from: http://www.foodsafetykorea.go.kr/foodcode/ index.jsp. Accessed at Feb 10, 2021.

Mora L, Sentandreu MA, Toldrá F. 2007. Hydrophilic chromatographic determination of carnosine, anserine, balenine, creatine, and creatinine. J Agric Food Chem 55: 4664-4669.

Patria CA, Afnan R, Arief II. 2016. Physical and microbiological qualities of kampong-broiler crossbred chickens meat raised in different stocking densities. Media Peternakan 39:141-147.

Re R, Pellegrini N, Proteggente A, Pannala A, Yang M, Rice-Evans C. 1999. Antioxidant activity applying an improved ABTS radical cation decolorization assay. Free Radical Biol Med 26:1231-1237.

Schilling MW, Radhakrishnan V, Thaxton YV, Christensen K, Thaxton JP, Jackson V. 2008. The effects of broiler catching method on breast meat quality. Meat Sci 79:163-171.

Schmid A. 2009. Bioactive substances in meat and meat products. Fleischwirtschaft 89:83-90.

Wang KH, Shi SR, Dou TC, Sun HJ. 2009. Effect of a free-range raising system on growth performance, carcass yield, and meat quality of slow-growing chicken. Poult Sci 88:2219-2223.

Wang T, Guo H, Zhang H, Ren F, Zhang M, Ge S, Luo H, Zhao L. 2019. Dynamics of bacterial communities of lamb meat packaged in air and vacuum pouch during chilled storage. Food Sci Anim Resour 39:209-221.

(c) Copyright. Korean Society for Food Science of Animal Resources.

Date Received Jul. 5, 2021

Date Revised Jul. 15, 2021

Date Accepted Jul. 15, 2021 